Article

\title{
Isolation and Characterization of a Novel Cold-Active, Halotolerant Endoxylanase from Echinicola rosea $\mathrm{Sp}$. Nov. JL3085 ${ }^{\mathrm{T}}$
}

\author{
Jianlong He ${ }^{1}$, Le Liu ${ }^{2}$, Xiaoyan Liu ${ }^{1}$ and Kai Tang ${ }^{2, *}$ \\ 1 Department of Chemistry and Chemical Engineering, Huaiyin Normal University, Huaian 223300, China; \\ jlhe@hytc.edu.cn (J.H.); lxy@hytc.edu.cn (X.L.) \\ 2 State Key Laboratory of Marine Environmental Science, Fujian Key Laboratory of Marine Carbon \\ Sequestration, College of Ocean and Earth Sciences, Xiamen University, Xiamen 361000, China; \\ liulezz3@163.com \\ * Correspondence: tangkai@xmu.edu.cn; Tel.: +86-592-218-5752
}

Received: 29 March 2020; Accepted: 3 May 2020; Published: 6 May 2020

\begin{abstract}
We cloned a xylanase gene (xynT) from marine bacterium Echinicola rosea sp. nov. JL3085 ${ }^{\mathrm{T}}$ and recombinantly expressed it in Escherichia coli BL21. This gene encoded a polypeptide with 379 amino acid residues and a molecular weight of $\sim 43 \mathrm{kDa}$. Its amino acid sequence shared $45.3 \%$ similarity with an endoxylanase from Cellvibrio mixtus that belongs to glycoside hydrolases family 10 (GH10). The XynT showed maximum activity at $40{ }^{\circ} \mathrm{C}$ and $\mathrm{pH} 7.0$, and a maximum velocity of $62 \mu \mathrm{moL} \mathrm{min}{ }^{-1} \mathrm{mg}^{-1}$. The XynT retained its maximum activity by more than $69 \%, 51 \%$, and $26 \%$ at $10{ }^{\circ} \mathrm{C}, 5^{\circ} \mathrm{C}$, and $0{ }^{\circ} \mathrm{C}$, respectively. It also exhibited the highest activity of $135 \%$ in the presence of $4 \mathrm{M}$ $\mathrm{NaCl}$ and retained $76 \%$ of its activity after $24 \mathrm{~h}$ incubation with $4 \mathrm{M} \mathrm{NaCl}$. This novel xylanase, XynT, is a cold-active and halotolerant enzyme that may have promising applications in drug, food, feed, and bioremediation industries.
\end{abstract}

Keywords: xylanase; endoxylanase; cold-active; halotolerance; marine; Echinicola rosea

\section{Introduction}

Hemicellulose, a highly abundant storage polysaccharides found in plants, accounts for $15-35 \%$ of the dry weight of plant cells [1]. It is mainly composed of xylan-based hemicellulose, which contains $\beta$-D-xylopyranosyl residues attached by $\beta-1,4$-glycosidic bonds [2]. Based on different substitutions on the $\beta$-D-xylopyranosyl backbone, xylan can be categorized into homoxylan, arabinoxylan, glucuronoxylan, and arabinoglucuronoxylan [3].

Several xylanolytic enzymes, such as $\alpha$-D-glucuronidase, endo- $\beta$-1,4-D-xylanase, $\alpha$-L-arabinofuranosidase, $\beta$-D-xylosidase, and acetylesterase are needed for the complete hydrolysis of xylan [4]. Of these, the endo- $\beta-1,4$-D-xylanase enzymes (EC 3.2.1.8) hydrolyzes the $\beta$-1,4-glycosidic bonds in the xylose chain. The endoxylanases are classified based on their three-dimensional catalytic domain, as can be determined by their amino acid sequences [5]. In the Carbohydrate-Active Enzyme (CAZy) database, endoxylanases are classified into glycoside hydrolase (GH) families 5, 8, 10, 11, 16, 26, 30, 43, 51 62, 98, and 141 [6], and the predominant families are the GH10 and GH11. The endoxylanases in the GH10 family possess a $(\beta / \alpha) 8$-barrel fold in their molecular structures, and the endoxylanases in GH11 family have a $\beta$-jelly roll fold $[7,8]$.

The metagenomic extraction of xylanases from variable sources, such as bacteria, yeast, fungi, and protozoa have been conducted, and metagenomic extraction using a culture-independent approach, and the environmental DNA of goat rumen contents have also been performed [9-14]. Xylanases have been utilized in many industrial and agricultural applications [15]. For instance, thermostable xylanases 
isolated from thermophilic microbes found in a hot spring have been utilized in the paper industry in various processes, including the kraft process and bio-bleaching of pulp [16,17]. Halotolerant xylanases have also been shown to have better efficiency when used in waste water treatment and paper industry $[18,19]$. Mesophilic xylanases, the most abundant type of xylanases, are used for clarifying fruit juices, for improving the consistency of beer, and for digesting animal feed stock [20,21]. Some textile and food-based industrial processes, as well as bioremediation, are carried out at low temperatures to stabilize product and avoid product denaturation [8]. Thus, some psychrophilic xylanases have been cloned from organisms found in streambed, Antarctic marine sponges, and seawater [9,10,22], and used in these low-temperature processes. The cold-active, halotolerant xylanase make an excellent additive for the detergent industry [23]. The enzymatic production of prebiotic oligosaccharides has gained more and more interest among researchers. Oligosaccharides can be utilized by the human gut microorganisms, such as Lactobacillus and Bifidobacterium, resulting the improvement of human health [24]. Functional oligosaccharides, including xylo-oligosaccharides (XOS), are difficult to digest in the human small intestine, due to the lack of corresponding digestive enzymes, but they are easily assimilated and metabolized by colon probiotic microorganisms, such as Lactobacillus and Bifidobacterium, so they are considered probiotics. Xylanase is an excellent tool to prepare XOS.

Marine xylanases exhibit some appealing characteristics, including cold adaption, hyperthermostability and halotolerancy, and the absence of cellulase activity, which differentiate them from terrestrial xylanases $[22,25,26]$. Therefore, marine xylanase can be operated in a wider scope of $\mathrm{pH}$, temperature, and salt concentrations. Herein, we cloned a novel GH10 endoxylanase gene from a halotolerant marine bacterium Echinicola rosea sp. nov. JL3085 ${ }^{\mathrm{T}}$ [27], and recombinantly expressed it in E. coli. Characterization of the purified recombinant enzyme showed that it is a cold-active and halotolerant endoxylanase. This study is the first report on the identification of an endoxylanase isolated from the genome of a bacterium in the genus Echinicola, which contains an extremely large number of GH genes [28].

\section{Results and Discussion}

\subsection{Production and Purification of Recombinant XynT}

The $x y n T$ gene (WP_137405116.1), which encodes 379 amino acid residues of a putative endoxylanase, was cloned from the genomic DNA of Echinicola rosea sp. nov. JL3085 ${ }^{\mathrm{T}}$. This protein had a theoretical molecular weight of $43275.95 \mathrm{Da}$, and its isoelectric point was 4.93. After expression and purification of the recombinant $\mathrm{XynT}$, the purified fractions were pooled and then subjected to enzymatic assays.

\subsection{Biochemical Characterization of the Recombinant XynT}

Hydrolysis of beechwood xylan by the purified recombinant XynT revealed that the primary products were xylotetraose, xylotriose, and xylobiose, and the monosaccharide xylose (X1) was produced at a very low amount, even at a prolonged hydrolysis time (Figure 1). Similar products, but with different concentrations, were obtained when birchwood xylan was used in the hydrolysis (data not shown). These results confirm that the recombinant XynT is a typical endoxylanase, which has no $\beta$-xylosidase activity. XynT produce smaller oligosaccharides without producing xylose, and thus, is suitable for the production of XOS. 


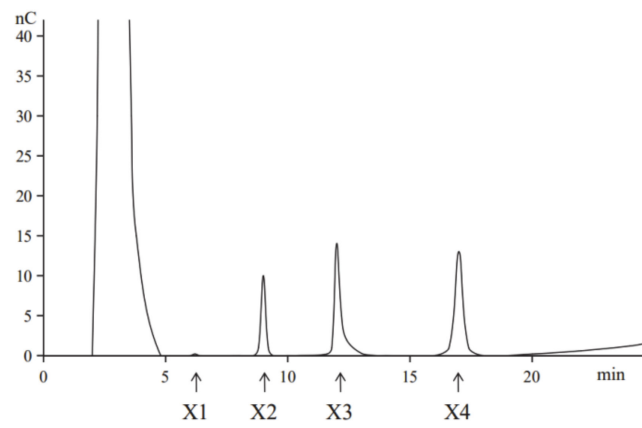

(a)

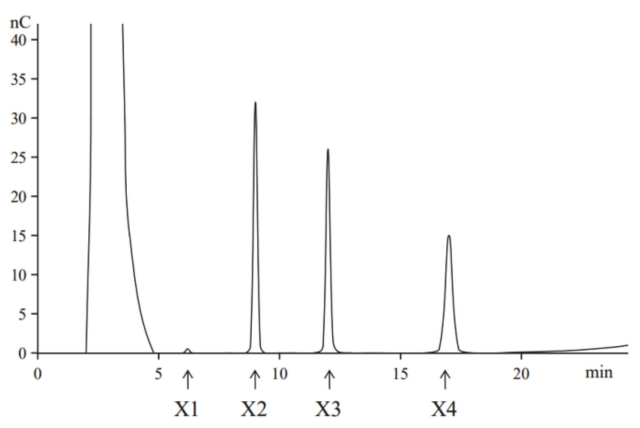

(b)

Figure 1. The high-performance anion-exchange chromatography (HPAEC) analysis of the hydrolysis of products of beechwood xylan performed at $40{ }^{\circ} \mathrm{C}$ for $2 \mathrm{~h} \mathrm{(a)} \mathrm{or} 8 \mathrm{~h}(\mathbf{b})$. Arrows indicate the positions of oligosaccharides: xylose (X1), xylobiose (X2), xylotriose (X3), and xylotetraose (X4).

XynT exhibited the maximum activity at $40{ }^{\circ} \mathrm{C}$ when beechwood xylan was used as the substrate (Figure 2a). The enzyme could retain its maximum activity by more than $69 \%, 51 \%$, and $26 \%$ at $10{ }^{\circ} \mathrm{C}$, $5{ }^{\circ} \mathrm{C}$, and $0{ }^{\circ} \mathrm{C}$, respectively. Figure $2 \mathrm{~b}$ shows the effects of $\mathrm{pH}$ on the activity of XynT. XynT was found to be a neutral xylanase that showed optimal activity between $\mathrm{pH} 6-7$, and was enzymatically active at $\mathrm{pH} 5-8$, as it retained activity at above $70 \%$ at this $\mathrm{pH}$ range.

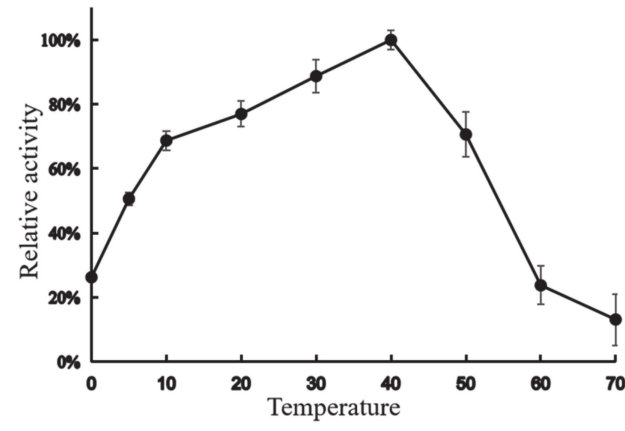

(a)

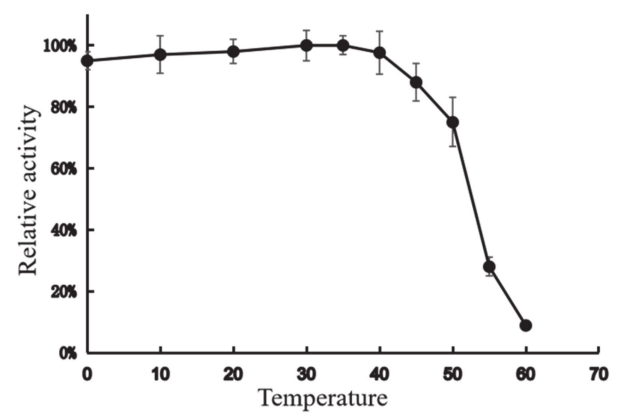

(c)

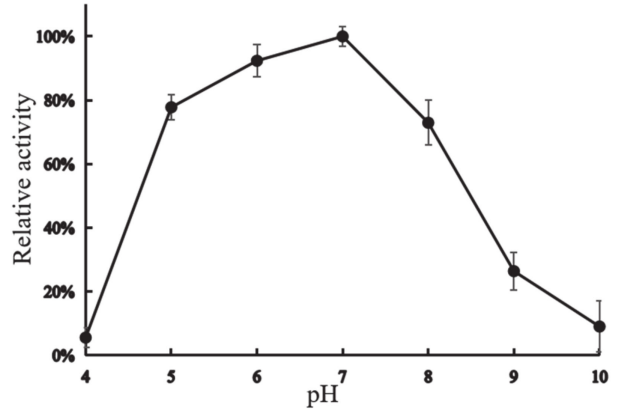

(b)

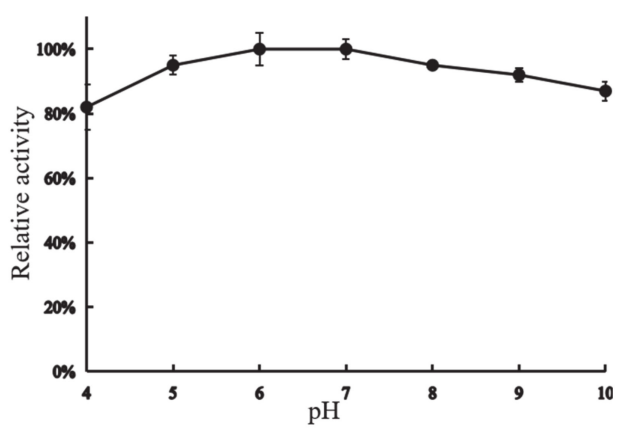

(d)

Figure 2. Activity profile of the xylanase gene (XynT) at various $\mathrm{pH}$ and temperatures. (a) XynT activity at $\mathrm{pH} 7$ at various temperatures. (b) XynT activity at $40{ }^{\circ} \mathrm{C}$ at a different $\mathrm{pH}$. (c) Effect of temperature on the stability of XynT. The residual activity of the enzyme was measured after incubation at $30-60{ }^{\circ} \mathrm{C}$ for $2 \mathrm{~h}$, and the residual activity was then assayed under standard conditions. (d) Effect of $\mathrm{pH}$ on the stability of XynT. The residual activity of the enzyme was measured after incubation at $\mathrm{pH} 4-10$ for $2 \mathrm{~h}$. 
XynT was stable at $0-40{ }^{\circ} \mathrm{C}$, but after incubation for $2 \mathrm{~h}$ at $50{ }^{\circ} \mathrm{C}$, XynT lost its activity by approximately less than $25 \%$, and almost completely lost all of its activity after incubation for $2 \mathrm{~h}$ at $60{ }^{\circ} \mathrm{C}$ (Figure 2c). Additionally, XynT was stable at $\mathrm{pH} 4-10$; it could retain more than $82 \%$ of its maximum activity after incubation at $4{ }^{\circ} \mathrm{C}$ for $2 \mathrm{~h}$ at this $\mathrm{pH}$ range (Figure $2 \mathrm{~d}$ ).

In general, the presence of metals such as $\mathrm{Mn}^{2+}, \mathrm{Cu}^{2+}, \mathrm{Co}^{2+}$, and $\mathrm{Fe}^{3+}$ can have negative impacts on industrial enzymes. $\mathrm{Cu}^{2+}$ is involved in the catalysis of auto-oxidation of cysteine residues, resulting in the formation of intermolecular and intramolecular disulfide bonds or the formation of sulfenic acid [29]. $\mathrm{Cu}^{2+}$ can also strongly inhibit activity of xylanasesfrom Sorangium cellulosum [30], Geobacillus thermoleovorans [31], and Plectosphaerella cucumerina [32]. $\mathrm{Mn}^{2+}$ has negative effects on activity of xylanases from Lechevalieria sp. [33] and Streptomyces viridochromogenes [34]. $\mathrm{Fe}^{3+}$ and $\mathrm{Co}^{2+}$ can cause dramatic decrease of activity of xylanases from G. mesophila KMM241 [35] and Sorangium cellulosum [30]. In this study, among all the metal ions tested, $\mathrm{Ca}^{2+}, \mathrm{K}^{+}, \mathrm{Zn}^{2+}, \mathrm{Cu}^{2+}$, and $\mathrm{Fe}^{3+}$ (each at $1 \mathrm{mM}$ ) showed no apparent effect on the activity of XynT; however, in the presence of $\mathrm{Co}^{2+}$, XynT could retain its activity by $40.94 \%$ (Figure 3$)$, and, in the presence of $\mathrm{Mn}^{2+}(1 \mathrm{mM})$, XynT could retain its activity by $12.08 \%$, indicating that $\mathrm{Mn}^{2+}$ had a high negative effect on XynT activity.

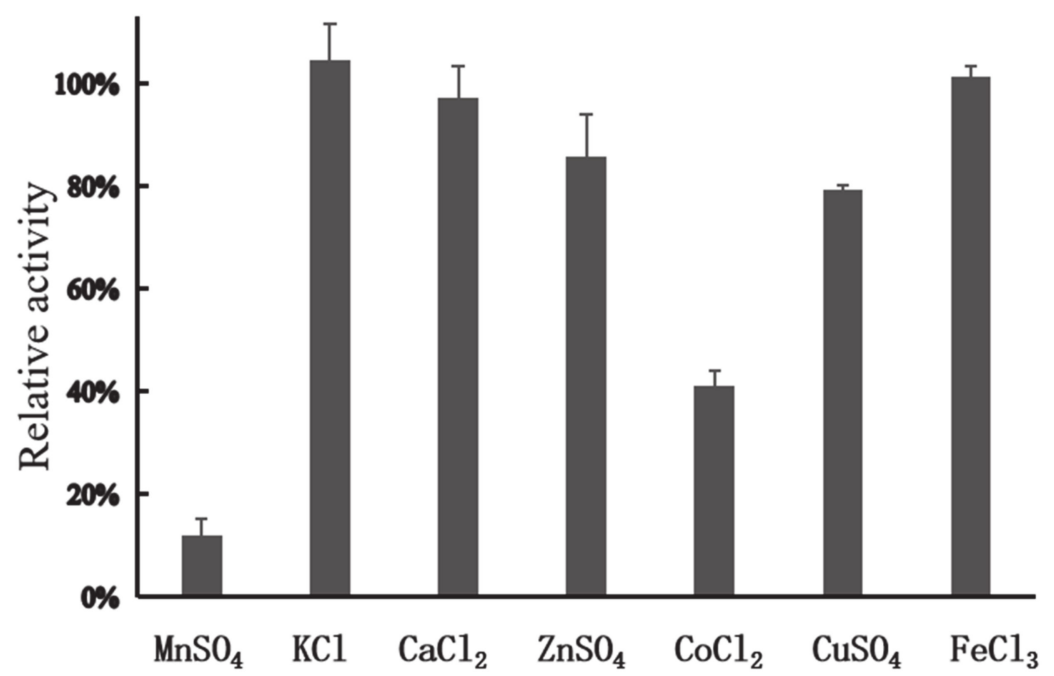

Figure 3. Effect of metal ions on the enzymatic activity of XynT. Effect of different metal ions, including $\mathrm{FeCl}_{3}, \mathrm{MnSO}_{4}, \mathrm{CaCl}_{2}, \mathrm{CoCl}_{2}, \mathrm{KCl}, \mathrm{ZnSO}_{4}$, and $\mathrm{CuSO}_{4}(1 \mathrm{mM})$, on the activity of $\mathrm{XynT}$ was investigated at $40{ }^{\circ} \mathrm{C}$ in a MclIvaine buffer ( $\left.\mathrm{pH} 7\right)$, using beechwood xylan ( $\left.1 \% \mathrm{w} / \mathrm{v}\right)$ as the substrate.

Interestingly, the presence of $1-4 \mathrm{M} \mathrm{NaCl}$ had positive effects on the activity of XynT (Figure 4a). At $4 \mathrm{M} \mathrm{NaCl}$, the activity of XynT increased by $135 \%$, compared to that in the absence of $\mathrm{NaCl}$, and the activity increased with the increase of concentration of $\mathrm{NaCl}$ (Figure 4a). XynT was found to be stable in the presence of $\mathrm{NaCl}$ : it retained approximately $76 \%$ of its activity in $4 \mathrm{M} \mathrm{NaCl}$, and approximately $107 \%$ in $2 \mathrm{M} \mathrm{NaCl}$, after $24 \mathrm{~h}$ incubation at $20^{\circ} \mathrm{C}$ (Figure $4 \mathrm{~b}$ ). These characteristics of XynT were similar to those of other cold-active, halotolerant xylanases isolated from various other microbes (Table 1). Thus, XynT belonged to the cold-active, halotolerant xylanase family. Compared with other xylanases, the cold adaption and halotolerancy of XynT are remarkable. Industrial process conditions are often conducted in extreme $\mathrm{pHs}$ and temperature, and the presence of salts may inhibit the enzymatic activity [36]. XynT have potential for industrial usage, especially in the processing of sea food and saline food from marine seaweeds. 


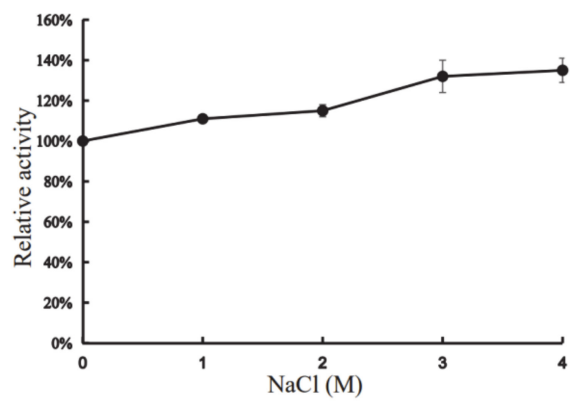

(a)

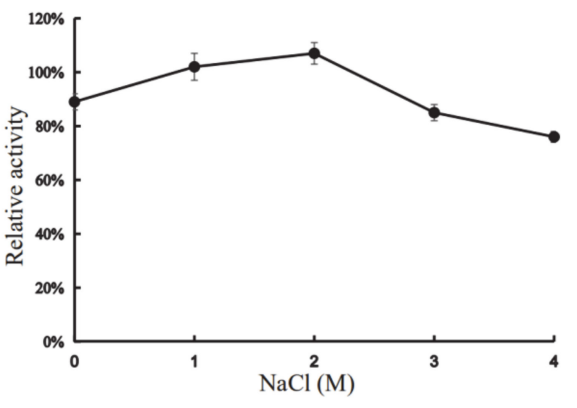

(b)

Figure 4. Effect of concentration of $\mathrm{NaCl}$ on the activity of XynT. (a) XynT activity at different concentrations of $\mathrm{NaCl}$. (b) Effect of different concentrations of $\mathrm{NaCl}$ on the stability of XynT. The residual activity of the enzyme was measured after incubation in different $\mathrm{NaCl}$ concentrations for $24 \mathrm{~h}$.

Table 1. Biochemical characteristics of xylanases.

\begin{tabular}{|c|c|c|c|c|c|c|}
\hline $\begin{array}{c}\text { Xylanase } \\
\text { (Source/Microorganism) }\end{array}$ & GH & $\mathrm{T}_{\text {opt }}{ }^{\circ} \mathrm{C}$ & $\mathrm{pH}_{\mathrm{opt}}$ & $\begin{array}{c}\text { Activity in the } \\
\text { Presence of } 4 \mathrm{M} \\
\mathrm{NaCl}\end{array}$ & $\begin{array}{l}\text { Residual Activity } \\
\text { at Low Temperature }\end{array}$ & Refs \\
\hline $\begin{array}{c}\text { XynT (Echinicola rosea sp. } \\
\text { nov. JL3085 } 5^{\mathrm{T}} \text { ) }\end{array}$ & 10 & 40 & 7 & $135 \%$ & $26 \%, 0^{\circ} \mathrm{C} ; 51 \%, 5^{\circ} \mathrm{C}$ & This study \\
\hline XynA (Zunongwangia profunda) & 10 & 30 & 6.5 & $140 \%$ & $23 \%, 0{ }^{\circ} \mathrm{C} ; 38 \%, 5^{\circ} \mathrm{C}$ & [22] \\
\hline $\begin{array}{c}\text { LaXynA (Luteinonas abyssi } \\
\text { XH031 }{ }^{\mathrm{T}} \text { ) }\end{array}$ & 10 & 40 & 7 & $100 \%$ & $51 \%, 10^{\circ} \mathrm{C}$ & {$[37]$} \\
\hline $\begin{array}{c}\text { XynRA2 (Roseithermus } \\
\text { sacchariphilus Strain RA) }\end{array}$ & 10 & 70 & 8.5 & $94 \%$ & $<30 \%, 20^{\circ} \mathrm{C}$ & [38] \\
\hline Xyn10A (Bacillus sp. SN5) & 10 & 40 & 7 & $<50 \%$ & $\sim 30 \%, 5^{\circ} \mathrm{C} ; \sim 30 \%, 10^{\circ} \mathrm{C}$ & [39] \\
\hline $\begin{array}{l}\text { Excg1 (Colletotrichum } \\
\text { graminicola) }\end{array}$ & 10 & 65 & 5.5 & $\begin{array}{c}\sim 100 \% \text { in } 3 \mathrm{M} \\
\mathrm{NaCl}\end{array}$ & & [40] \\
\hline $\begin{array}{l}\text { Xyn10A (Flavobacterium } \\
\text { johnsoniae) }\end{array}$ & 10 & 30 & 8 & & $50 \%, 4^{\circ} \mathrm{C}$ & [41] \\
\hline Xyn11 (Bispora antennata) & 11 & 35 & 5.5 & & $20 \%, 0{ }^{\circ} \mathrm{C} ; \sim 40 \%, 10^{\circ} \mathrm{C}$ & [42] \\
\hline $\begin{array}{c}\text { XynGR40 (goat rumen } \\
\text { contents) }\end{array}$ & 10 & 30 & 6.5 & & $10 \%, 0{ }^{\circ} \mathrm{C}$ & [12] \\
\hline $\begin{array}{c}\text { Xylanase (Pseudoalteromonas } \\
\text { haloplanktis) }\end{array}$ & 8 & 35 & $5.3-8$ & & $60 \%, 5{ }^{\circ} \mathrm{C}$ & [43] \\
\hline $\begin{array}{c}\text { XynBE18 (Paenibacillus sp. } \\
\text { Strain E18) }\end{array}$ & 10 & 50 & $7-9$ & & $\sim 30 \%, 30^{\circ} \mathrm{C}$ & [44] \\
\hline $\begin{array}{c}\text { XynA19 (Sphingobacterium sp. } \\
\text { TN19) }\end{array}$ & 10 & 45 & $6-6.5$ & & $<10 \%, 0{ }^{\circ} \mathrm{C}$ & [45] \\
\hline
\end{tabular}

\subsection{Kinetic Study of XynT}

The hydrolysis of beechwood xylan $(10 \mathrm{mg} / \mathrm{mL})$ revealed that with the increase of reaction time, xylanase activity increased in the first $20 \mathrm{~min}$. Therefore, the kinetic parameters were determined at a reaction time of $20 \mathrm{~min}$ and at temperatures of $10^{\circ} \mathrm{C}$ and $40{ }^{\circ} \mathrm{C}$. The $\mathrm{V}_{\max }$ of the isolated XynT was $15 \mu \mathrm{moL} \mathrm{min}{ }^{-1} \mathrm{mg}^{-1}$ at $10^{\circ} \mathrm{C}$, and that significantly increased to $62 \mu \mathrm{moL} \mathrm{min}{ }^{-1} \mathrm{mg}^{-1}$ at $40^{\circ} \mathrm{C}$ (Table 2). The $K_{m}$ value for XynT decreased from $22.7 \mathrm{mM}$ to $15.3 \mathrm{mM}$, as the temperature increased from $10^{\circ} \mathrm{C}$ to $40{ }^{\circ} \mathrm{C}$. The $k_{\text {cat }}$ values increased with increasing temperature, and the $k_{\text {cat }} / K_{m}$ value at $40{ }^{\circ} \mathrm{C}$ was 8.3 times higher than that at $10^{\circ} \mathrm{C}$.

Table 2. Kinetic parameters of XynT in hydrolysis of beechwood xylan.

\begin{tabular}{ccccc}
\hline $\begin{array}{c}\text { Temperature } \\
{ }^{\circ} \mathbf{C}\end{array}$ & $\begin{array}{c}\mathbf{V}_{\text {max }} \\
\boldsymbol{\mu m o L ~} \mathbf{~ m i n}^{-\mathbf{1}} \mathbf{~ m g}^{-\mathbf{1}}\end{array}$ & $\begin{array}{c}\boldsymbol{K}_{m} \\
\mathbf{m M}\end{array}$ & $\begin{array}{c}\boldsymbol{k}_{\text {cat }} \\
\mathbf{S}^{-\mathbf{1}}\end{array}$ & $\begin{array}{c}\boldsymbol{k}_{\text {cat }} / \boldsymbol{K}_{m} \\
\mathbf{S}^{-\mathbf{1}} \mathbf{~} \mathbf{M}\end{array}$ \\
\hline 10 & $15 \pm 0.7$ & $22.7 \pm 2.7$ & $9 \pm 0.4$ & 0.4 \\
\hline 40 & $62 \pm 1.5$ & $15.3 \pm 1.3$ & $51 \pm 1.3$ & 3.3 \\
\hline
\end{tabular}




\subsection{Sequence Analysis and Structural Modeling of XynT}

The signal peptide analysis revealed that the cleavage site of the signal peptide in XynT lay between Ala21 and Cys22. This cleavage site produced a 358-residue. BLASTp was used to search the mature XynT sequence in the GenBank protein database, and it showed that XynT belongs to the GH10 family, and contains one catalytic domain, and it does not contain a carbohydrate-binding module. The search also showed that XynT and endoxylanase from Cellvibrio mixtus share the highest similarity $(45.3 \%)$.

A previous report has shown that, unlike non-halophilic proteins, halotolerant proteins contain an abundance of acidic amino acids on their surfaces [46]. The high water-binding capacity of these acidic amino acids facilitates the formation of a solvation shell on the protein surface, which can keep them hydrated and assist in the adaptation of the proteins to the high salt concentration-induced environmental pressure [23,47]. A halophilic dihydrolipoamide dehydrogenaseenzyme lost its halo-activity when two of the Glu residues in the interface of the enzyme were replaced by neutral amino acids [48]. It was suggested Glu plays a key role of halo-stablity. XynT contains 26 Asp residues and $35 \mathrm{Glu}$ residues, which accounted for $17.1 \%$ of the entire amino acid sequence, and is the highest ratio among all amino acids (Table 3). Xylanase (XynA) from Zunongwangia profunda posseses $16.3 \%$ acidic amino acids, which activity was significantly increased $140 \%$ at $4 \mathrm{M} \mathrm{NaCl}$, however, it only retained $\sim 60 \%$ activtiy after 2 -h incubation with $4 \mathrm{M} \mathrm{NaCl}$ [22]. A halotolerant glucanase from metagenomics of seaweed-associated microbiota posseses $13.8 \%$ acidic amino acids, which remained $97 \%$ active after a 24-h incubation with $4 \mathrm{M} \mathrm{NaCl}$ [11]. These results suggest that high halo-stability of $\mathrm{XynT}$ may be associated with its high proportion of acidic amino acids.

To uncover the structure of XynT, the SWISS-MODEL using the crystal structure of CmXyn10B from Cellvibrio mixtus (Protein Data Bank entry: 2cnc.1.A) [49] as the template was employed to build a structural model of mature XynT (residues 22-379). The overall structure of the model had a MolProbity score of 1.73 and a Verify 3D score of $94.8 \%$, indicating that it has good quality. The predicted structure of XynT also possessed the characteristic ( $\beta / \alpha) 8$-barrel fold of GH10 xylanases (Figure 5 ).

Table 3. Amino acid composition and putative parameters affecting the stability and flexibility of xylanases.

\begin{tabular}{|c|c|c|c|c|c|c|c|c|}
\hline Composition/Parameter & XynT & XynA & XynGR40 & XynA19 & Xyn10A & xylanase & XynRA2 & LaXynA \\
\hline Percent Gly (\%) & 7.5 & 5.3 & 7.6 & 6.8 & 5.2 & 7.3 & 9.3 & 9.9 \\
\hline $\mathrm{T}_{\text {opt }}\left({ }^{\circ} \mathrm{C}\right)$ & 40 & 30 & 30 & 45 & 40 & 35 & 70 & 40 \\
\hline Arg/Lys ratio & 0.82 & 0.38 & 0.5 & 0.52 & 0.25 & 0.43 & 5.3 & 6.88 \\
\hline Percent alkaline amino acid (\%) & 13.6 & 17.9 & 13.5 & 15.2 & 11.4 & 10.6 & 7.4 & 9.3 \\
\hline Percent acidic amino acid $(\%)$ & 17.1 & 16.3 & 13.7 & 13 & 11.4 & 8 & 14.7 & 14.2 \\
\hline Reference & This study & [22] & [12] & [45] & [41] & [43] & [38] & [37] \\
\hline
\end{tabular}

$\mathrm{T}_{\mathrm{opt}}$ : optimal temperature. Alkaline amino acids include Arginine (Arg), Histidine (His) and Lysine (Lys).

Acidic amino acids include Aspartic acid (Asp) and Glutamic acid (Glu).

The amino acid sequence of XynT showed 18.7-56.2\% similarity with xylanases from Sphingobacterium sp. XynA19 [45], Bacillus sp. Xyn10A [39], Paenibacillus sp. XynBE18 [44], Zunongwangia profunda XynA [22], XynGR40 from goat rumen contents [50], and Flavobacterium johnsoniae Xyn10A [41]. Xylanase family 10 enzymes can catalyze the hydrolysis of substrates through the double displacement mechanism, classifying as retaining enzyme. The multiple sequence alignment of six GH10 xylanases, in addition to comparing their crystal structures, showed that the putative catalytic residues of XynT were Glu164 and Glu269 (Figure 6). The amino acid sequences of XynT, one GH11 xylanase, one GH8 xylanase, and ten GH10 xylanases, among which two xylanases are from fungi, one xylanase is thermophilic, and seven xylanases are psychrophilic, were used to construct a phylogenetic tree (Figure 7). The GH8 xylanase and the GH11 xylanase are the far homologs of GH10 xylanases, whereas two other xylanases are the close homologs. Additionally, the thermophilic xylanase and LaXynA are the far homolog of GH10 xylanases, and other seven psychrophilic xylanases are the close homologs. 


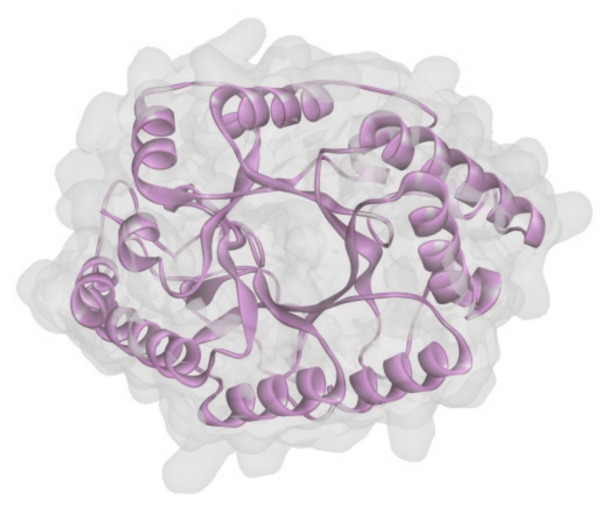

Figure 5. Structure modeling of XynT.

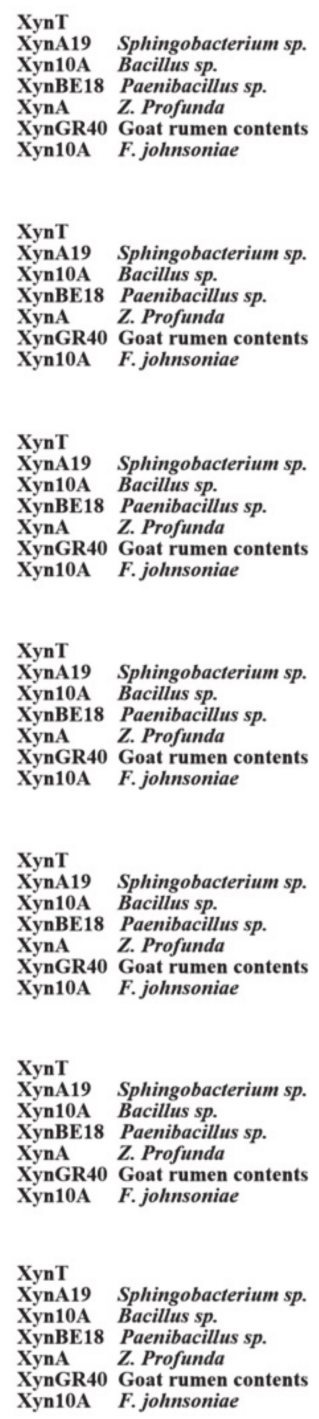

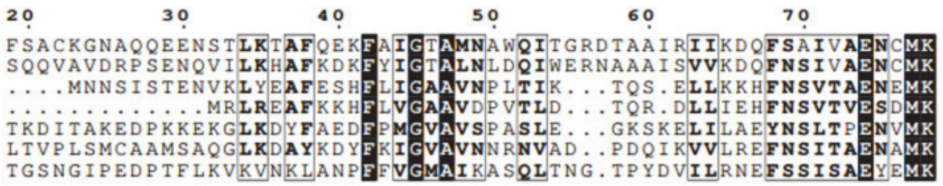

TGSNGIPCAAMSAQGLKDAYKDYFKIIGVAVNNRNVAD.. PDQI KVVLREFNSITAENAMK
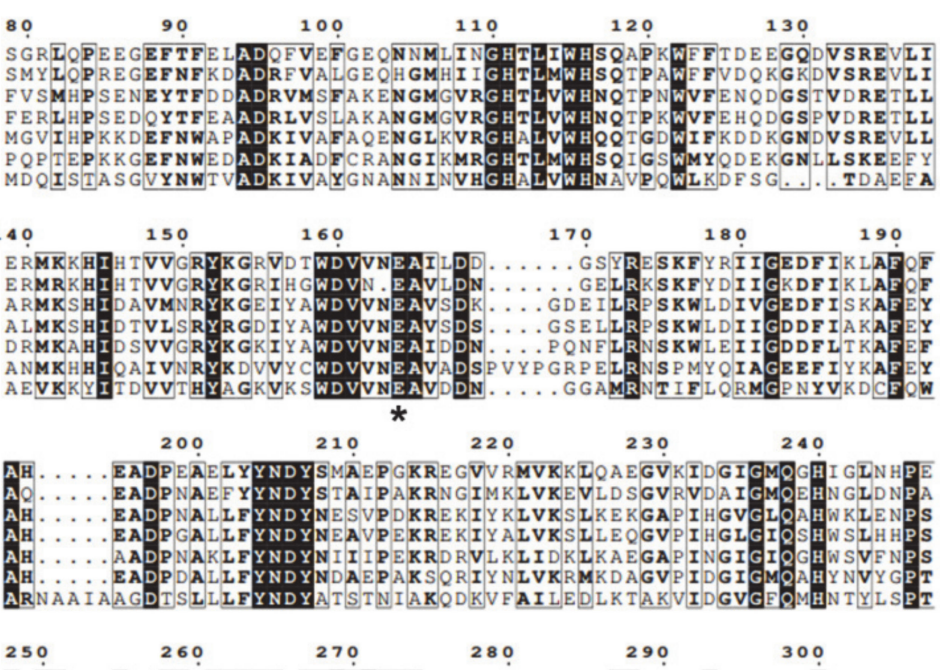

IR $\dot{E} F E$ KS IE AFAGIGVEVMVTELDITVLP SP WD DQGAEVSKNF D Y ED KMNPF PंD GLPDEV LSEVEKTIVGFASLGTKVMVTEMDISVLPHVNPNMGAE ISETY QYKNELNP YQE GLPDAI LDL IRQAIERYASLGLKLHITELDVSVFEHED $\ldots \ldots$ KRTDLKEPTTYMMERQA $\ldots \ldots$

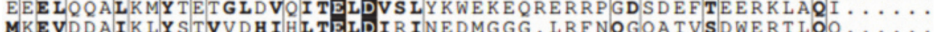

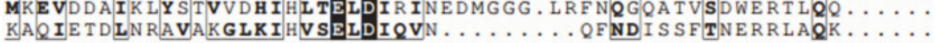

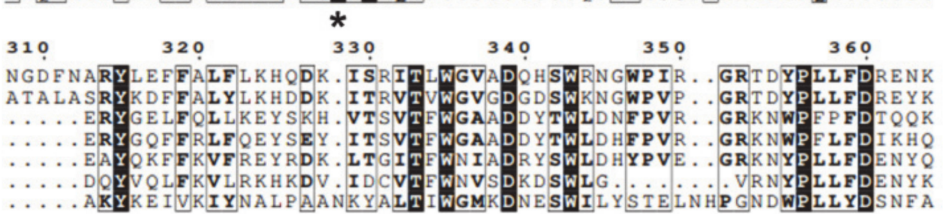

370

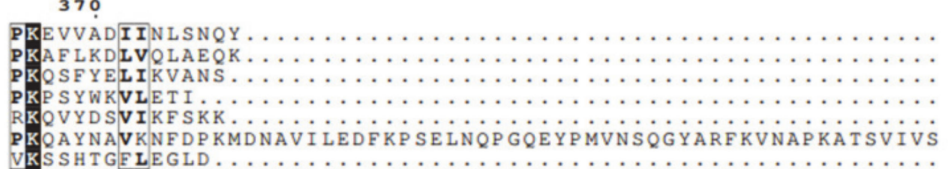

Figure 6. Multiple sequence alignment of XynT with six GH10 cold-active xylanases, including XynA19 from Sphingobacterium sp. TN19, Xyn10A from Bacillus sp. SN5, XynBE18 from Paenibacillus sp. Strain E18, XynA from Zunongwangia profunda, XynGR40 from goat rumen, and Xyn10A from Flavobacterium johnsoniae. Solid black and grey boxes highlight the identical and similar amino acids, respectively. Two conserved catalytic residues (Glu) are asterisked. 


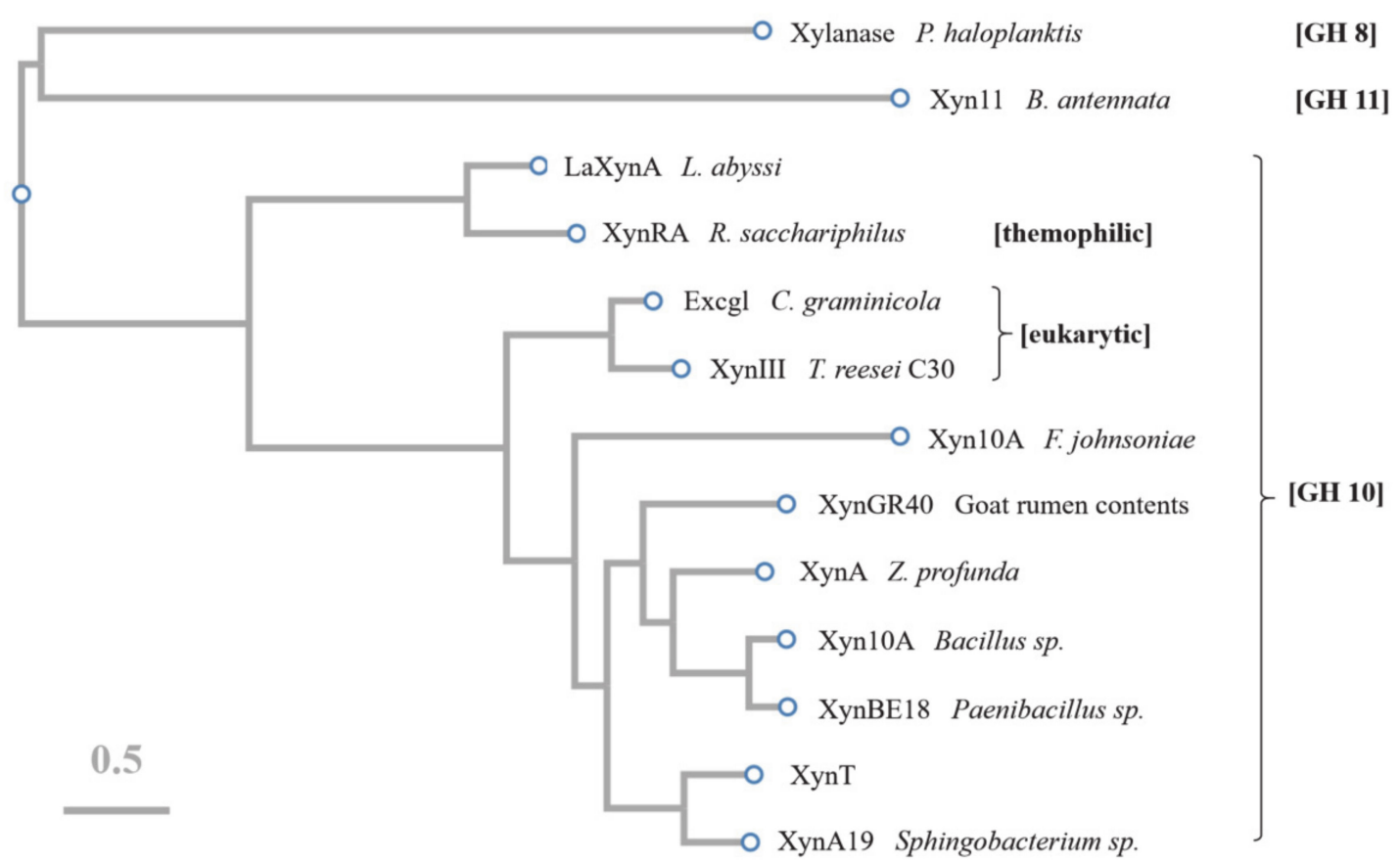

Figure 7. Phylogenetic tree constructed using CLUSTAW of GH11 xylanase (Xyn11) from Bispora antennata, GH8 xylanase from Pseudoalteromonas haloplanktis, GH10 xylanases (LaXynA) from Luteinonase abyssi XH031T, XynRA2 from Roseithermus sacchariphilus Strain RA, Excg1 from Colletotrichum graminicola, XynIII from Trichoderma reesei C30, Xyn10A from Flavobacterium johnsoniae, XynGR40 directly from goat rumen, XynA from Zunongwangia profunda, Xyn10A from Bacillus sp. SN5, XynBE18 from Paenibacillus sp. Strain E18, XynA19 from Sphingobacterium sp. TN19, and XynT presented in this study.

XynT also exhibited significant activity even at cold condition. The structural flexibility may contribute to their enhanced enzymatic activity at low temperatures [51]. Some psychrophilic enzymes have low numbers of glycine residues, disulfide bonds, and salt bridges [45]. Similarly, XynT does not contain disulfide bonds, while it contains only 15 salt bridges, and 7.5\% Gly residues. Most cold-adapted enzymes, including phosphoglycerate kinase [52], galactosidase [53], and chitobiase [54], have a low Arg/Lys ratio. XynRA2 from R. sacchariphilus, which is a thermophilic xylanase with the optimal temperature of $70^{\circ} \mathrm{C}$, has a high Arg/Lys ratio. Several other psychrophilic enzymes have also been reported to have higher Arg/Lys ratios, compared to their thermostable homologs [51]. Similarly to our results, XynT (Arg/Lys ratio = 0.82) and other psychrophilic xylanases had low Arg/Lys ratios, whereas LaXynA from L. abyssi had a high Arg/Lys ratio of 6.88 (Table 3).

\section{Materials and Methods}

\subsection{Materials}

Table S1 lists the bacterial strains, primers, and plasmids that were used in this study. Plasmids were propagated in E. coli DH5 $\alpha$ (the transformation hosts) and were subsequently transformed into E. coli BL21 (DE3). Substrates including beechwood xylan, birchwood xylan, xylotetraose (X4), xylotriose (X3), and xylobiose (X2) were procured from Megazyme. All other chemicals were of analytical grade.

\subsection{Growth Conditions, Enzymatic Assay, and Determination of Kinetic Parameters}

Escherichia coli was grown in LB medium at $37{ }^{\circ} \mathrm{C}$ in a flask shaken at $200 \mathrm{rpm}$. Echinicola rosea JL3085 $5^{\mathrm{T}}$ was grown in 2216E medium (Hopebio, Qingdao, China) at $30{ }^{\circ} \mathrm{C}$ in a flask shaken at $200 \mathrm{rpm}$ [55]. Determination of xylanase activity has been previously described [39]. The kinetic parameters, $K_{m}, \mathrm{~V}_{\max }$, and $k_{c a t}$, were determined according to a previously described method [37]. 


\subsection{Cloning, Expression and Purification of E. roseaxynt in E. coli}

General molecular biology techniques have been described previously [56]. The pET-22b(+) plasmid was linearized using EcoRI restriction enzyme (TaKaRa, Ohtsu, Japan). The gene sequence of $x y n T$ was amplified from genomic DNA using the primers XynT_F and XynT_R. The xynT gene was inserted into the linearized pET-22b(+) using Seamless cloning kit (Beyotime, Shanghai, China) to construct the expression plasmid (pET22b_xynT), and the heat shock method was then used to transform the plasmid into E. coli BL21 (DE3). The restriction digestion, along with DNA sequencing using an ABI3100 (Applied Biosystems, Foster City, California), were used to identify the transformants. Next, the positive transformant (transformant containing pET22b_xynT) was grown in LB medium at $37^{\circ} \mathrm{C}$ in the presence of $100 \mu \mathrm{g} / \mathrm{mL}$ ampicillin (Merck, Germany), until an $\mathrm{OD}_{600}$ of 0.6 was achieved. Isopropyl- $\beta$-D-1-thiogalactopyranoside (IPTG, $1 \mathrm{mM}$ ) was added at $25^{\circ} \mathrm{C}$ for $12 \mathrm{~h}$, to induce protein expression.

The sample was centrifuged at $12,000 \times g$ and $4{ }^{\circ} \mathrm{C}$ for $5 \mathrm{~min}$, the cultured supernatant was collected and concentrated using a Pierce $^{\mathrm{TM}}$ protein concentrator (PES 5K MWCO; ThermoFisher). The recombinant protein was purified from the concentrated supernatant through its His-tagged sequence using the BeyoGold ${ }^{\mathrm{TM}}$ his-tag purification resin (Beyotime, Shanghai, China). The recombinant XynT was separated by SDS-PAGE to determine its molecular mass and purity. The Bradford assay kit was used to determine the protein concentration (Beyotime, Shanghai, China).

\subsection{Effect of $\mathrm{pH}$ on the Stability of Recombinant XynT}

The optimal $\mathrm{pH}$ for the enzymatic activity of XynT was determined using buffers with $\mathrm{pH} 4-10$ at $40{ }^{\circ} \mathrm{C}$, and beechwood xylan $(1 \% \mathrm{w} / \mathrm{v})$ was used as the substrate. The enzyme was incubated in buffers with different $\mathrm{pH}$ at $4{ }^{\circ} \mathrm{C}$ for $2 \mathrm{~h}$ and its $\mathrm{pH}$ stability was determined based on its residual activity at $\mathrm{pH}$ 7. The buffers that were used for this enzymatic assay were Mcllvaine buffer, $\mathrm{pH} 4-8$ and $50 \mathrm{mM}$ glycine-NaOH buffer, $\mathrm{pH} 9-10$.

\subsection{Effect of Temperature on the Stability of Recombinant XynT}

Thermostability was determined in MclIvaine buffer ( $\mathrm{pH} 7)$ using beechwood xylan ( $1 \% \mathrm{w} / \mathrm{v}$ ) as the substrate at a temperature range of 0 to $70{ }^{\circ} \mathrm{C}$. The residual activity of the enzyme was measured at $40^{\circ} \mathrm{C}$ post-incubation for $2 \mathrm{~h}$ at $0-60^{\circ} \mathrm{C}$.

\subsection{Effect of Metal Ions on the Activity of Recombinant XynT}

The effects of different metal ions, including $\mathrm{FeCl}_{3}, \mathrm{MnSO}_{4}, \mathrm{CaCl}_{2}, \mathrm{CoCl}_{2}, \mathrm{KCl}, \mathrm{ZnSO}_{4}$, and $\mathrm{CuSO}_{4}$ (each at a final concentration of $1 \mathrm{mM}$ ), on the activity of $\mathrm{XynT}$ were investigated at $40{ }^{\circ} \mathrm{C}$ in Mcllvaine buffer ( $\mathrm{pH} 7)$, using beechwood xylan $(1 \% \mathrm{w} / \mathrm{v})$ as the substrate.

\subsection{Effect of Salt on the Activity of Recombinant XynT}

The effects of different salt concentrations, $0-4 \mathrm{M} \mathrm{NaCl}$, on xylanase activity was evaluated at $\mathrm{pH}$ 7 and $40^{\circ} \mathrm{C}$. The halotolerance of the enzyme was evaluated by incubating the enzyme at $20^{\circ} \mathrm{C}$ in the presence of $0-4 \mathrm{M} \mathrm{NaCl}$ for $24 \mathrm{~h}$, and then measuring its residual activity at $40^{\circ} \mathrm{C}$.

In analysis of hydrolysis, the purified XynT was incubated with beechwood xylan or birchwood xylan at $40{ }^{\circ} \mathrm{C}$ in Mcllvaine buffer ( $\mathrm{pH} 7$ ) for $2 \mathrm{~h}$ or $8 \mathrm{~h}$. Thereafter, the enzyme was removed using a Pierce $^{\mathrm{TM}}$ protein concentrator (PES 5K MWCO; ThermoFisher). A high-performance anion-exchange chromatography (HPAEC, ICS-3000 system) equipped with a CarboPac MA1 column (Dionex, CA, USA) was used to analyzed the enzyme, and $0.1 \mathrm{M} \mathrm{NaOH}$ and $0.2 \mathrm{M} \mathrm{NaAc}$ were used as the solvents.

\subsection{Putative Structure Analysis}

The BLASTp program was used to search the amino acid sequence of XynT against the NCBI database. Homology modeling using SWISS-MODEL was used to generate a three-dimensional model 
of XynT [57]. The assessment of the predicted model was carried out on Molprobity and Verify 3D [58,59]. SignalP 5.0 was used for signal peptide prediction [60]. Multiple sequence alignment was performed using CLUSTALW and ESPript3.0 [61]. Disulfide bonds and salt bridges (distances $\leq 3.2 \AA$ ), were predicted based on a previously described method [12,62]. The model structure was analyzed by Discovery studio software.

\section{Conclusions}

In this study, we cloned xynT, a novel xylanase gene from a halotolerant bacterium Echinicola rosea sp. nov. JL3085 ${ }^{\mathrm{T}}$. Biochemical characterization and structural analysis showed that XynT protein belonged to the cold-active, halotolerant xylanase family, and exhibited a high catalytic activity at high salt concentrations $(4 \mathrm{M} \mathrm{NaCl})$, among other known $\mathrm{GH}$ family 10 psychrophilic xylanases. XynT could digest xylan to produce smaller oligosaccharides, without producing xylose, thus is suitable for the production of XOS, which could improve the growth prebiotic bacteria of Lactobacillus and Bifidobacterium. XOS of various polymerization degrees would have more potential functions, which is governed by their substitution patterns [23]. But it has been difficult to produce specific XOS using some chemical and physical methods. Enzymatic transformation of xylan into XOS using XynT is a promising technical route for production of various substituted XOS. The presented XynT may be used to study the structure-function relationship in cold-active enzymes, and have potential applications in the bleaching of paper and pulp, bioremediation, food, and the human health sector, especially in seaweeds and medicine processing as a tool to prepare prebiotics.

Supplementary Materials: The following are available online at http://www.mdpi.com/1660-3397/18/5/245/s1, Table S1: Bacterial strains, plasmids, and primers used.

Author Contributions: Conceptualization, K.T.; methodology, J.H. and L.L.; software, L.L.; validation, X.L.; formal analysis; J.H.; investigation, X.L.; resources, K.T.; data curation, J.H. and L.L; writing - original draft preparation, J.H. and L.L.; writing - review and editing, K.T.; visualization, K.T.; supervision, K.T.; project administration, K.T.; funding acquisition, K.T. All authors have read and agreed to the published version of the manuscript.

Funding: This study was supported by the National Natural Science Foundation of China project (91751207, 41776167, U1805242, 41861144018), China Ocean Mineral Resources R \& D Association (DY135-E2-1-04).

Conflicts of Interest: The authors declare no conflict of interest.

\section{References}

1. Limayem, A.; Ricke, S.C. Lignocellulosic biomass for bioethanol production: Current perspectives, potential issues and future prospects. Prog. Energy Combust. Sci. 2012, 38, 449-467. [CrossRef]

2. Koukiekolo, R.; Cho, H.-Y.; Kosugi, A.; Inui, M.; Yukawa, H.; Doi, R.H. Degradation of Corn Fiber by Clostridium cellulovorans Cellulases and Hemicellulases and Contribution of Scaffolding Protein CbpA. Appl. Environ. Microbiol. 2005, 71, 3504-3511. [CrossRef]

3. Naidu, D.S.; Hlangothi, S.P.; John, M. Bio-based products from xylan: A review. Carbohydr. Polym. 2018, 179, 28-41. [CrossRef] [PubMed]

4. Moreira, L.; Filho, E.X.F. Insights into the mechanism of enzymatic hydrolysis of xylan. Appl. Microbiol. Biotechnol. 2016, 100, 5205-5214. [CrossRef] [PubMed]

5. Henrissat, B.; Bairoch, A. Updating the sequence-based classification of glycosyl hydrolases. Biochem. J. 1996, 316, 695-696. [CrossRef] [PubMed]

6. Lombard, V.; Golaconda Ramulu, H.; Drula, E.; Coutinho, P.M.; Henrissat, B. The Carbohydrate-active enzymes database (CAZy) in 2013. Nucleic Acids. Res. 2014, 42, D490-D495. [CrossRef]

7. Wang, K.; Luo, H.-Y.; Tian, J.; Turunen, O.; Huang, H.; Shi, P.; Hua, H.; Wang, C.; Wang, S.; Yao, B. Thermostability Improvement of a Streptomyces Xylanase by Introducing Proline and Glutamic Acid Residues. Appl. Environ. Microbiol. 2014, 80, 2158-2165. [CrossRef]

8. Collins, T.; Gerday, C.; Feller, G. Xylanases, xylanase families and extremophilic xylanases. FEMS Microbiol. Rev. 2005, 29, 3-23. [CrossRef] 
9. Lee, C.C.; Smith, M.; Kibblewhite-Accinelli, R.E.; Williams, T.G.; Wagschal, K.; Robertson, G.H.; Wong, D.W.S. Isolation and Characterization of a Cold-Active Xylanase Enzyme from Flavobacterium sp. Curr. Microbiol. 2006, 52, 112-116. [CrossRef]

10. Del-Cid, A.; Ubilla, P.; Ravanal, M.-C.; Medina, E.; Vaca, I.; Levicán, G.; Eyzaguirre, J.; Chávez, R. Cold-Active Xylanase Produced by Fungi Associated with Antarctic Marine Sponges. Appl. Biochem. Biotechnol. 2013, 172, 524-532. [CrossRef]

11. Martin, M.; Biver, S.; Steels, S.; Barbeyron, T.; Jam, M.; Portetelle, D.; Michel, G.; Vandenbol, M. Identification and Characterization of a Halotolerant, Cold-Active Marine Endo- $\beta-1,4$-Glucanase by Using Functional Metagenomics of Seaweed-Associated Microbiota. Appl. Environ. Microbiol. 2014, 80, 4958-4967. [CrossRef]

12. Wang, G.; Luo, H.-Y.; Wang, Y.; Huang, H.; Shi, P.; Yang, P.; Meng, K.; Bai, Y.G.; Yao, B. A novel cold-active xylanase gene from the environmental DNA of goat rumen contents: Direct cloning, expression and enzyme characterization. Bioresour. Technol. 2011, 102, 3330-3336. [CrossRef] [PubMed]

13. Béra-Maillet, C.; Devillard, E.; Cezette, M.; Jouany, J.-P.; Forano, E. Xylanases and carboxymethylcellulases of the rumen protozoaPolyplastron multivesiculatum,Eudiplodinium maggiiandEntodiniumsp. FEMS Microbiol. Lett. 2005, 244, 149-156. [CrossRef]

14. Petrescu, I.; Lamotte-Brasseur, J.; Chessa, J.-P.; Ntarima, P.; Claeyssens, M.; Devreese, B.; Marino, G.; Gerday, C. Xylanase from the psychrophilic yeast Cryptococcus adeliae. Extremophiles 2000, 4, 137-144. [CrossRef]

15. Juturu, V.; Wu, J. Microbial xylanases: Engineering, production and industrial applications. Biotechnol. Adv. 2012, 30, 1219-1227. [CrossRef]

16. Karlsson, O.; Pettersson, B.; Westermark, U. Linkages between residual lignin and carbohydrates in bisulphite (Magnefite) pulps. J. Pulp Pap. Sci. 2001, 27, 310-316.

17. Kumar, V.; Marín-Navarro, J.; Shukla, P. Thermostable microbial xylanases for pulp and paper industries: Trends, applications and further perspectives. World J. Microbiol. Biotechnol. 2016, 32, 34. [CrossRef]

18. Zhao, Y.; Luo, H.; Meng, K.; Shi, P.; Wang, G.; Yang, P.; Yuan, T.; Yao, B. A Xylanase Gene Directly Cloned from the Genomic DNA of Alkaline Wastewater Sludge Showing Application Potential in the Paper Industry. Appl. Biochem. Biotechnol. 2011, 165, 35-46. [CrossRef] [PubMed]

19. Zhao, Y.; Meng, K.; Luo, H.; Huang, H.; Yuan, T.; Yang, P.; Yao, B. Molecular and biochemical characterization of a new alkaline active multidomain xylanase from alkaline wastewater sludge. World J. Microbiol. Biotechnol. 2012, 29, 327-334. [CrossRef] [PubMed]

20. Wong, K.K.; Tan, L.U.; Saddler, J.N. Multiplicity of beta-1,4-xylanase in microorganisms: Functions and applications. Microbiol. Rev. 1988, 52, 305-317. [CrossRef] [PubMed]

21. Subramaniyan, S.; Prema, P. Biotechnology of Microbial Xylanases: Enzymology, Molecular Biology, and Application. Crit. Rev. Biotechnol. 2002, 22, 33-64. [CrossRef]

22. Liu, X.; Huang, Z.; Zhang, X.; Shao, Z.; Liu, Z. Cloning, expression and characterization of a novel cold-active and halophilic xylanase from Zunongwangia profunda. Extremophiles 2014, 18, 441-450. [CrossRef]

23. Setati, M.E. Diversity and industrial potential of hydrolase-producing halophilic/halotolerant eubacteria. Afr. J. Biotechnol. 2010, 9, 1555-1560. [CrossRef]

24. Karlsson, E.N.; Schmitz, E.; Linares-Pastén, J.A.; Adlercreutz, P. Endo-xylanases as tools for production of substituted xylooligosaccharides with prebiotic properties. Appl. Microbiol. Biotechnol. 2018, 102, 9081-9088. [CrossRef]

25. Hou, Y.-H.; Wang, T.-H.; Long, H.; Zhu, H.-Y. Novel Cold-adaptive Penicillium Strain FS010 Secreting Thermo-labile Xylanase Isolated from Yellow Sea. Acta Biochim. et Biophys. Sin. 2006, 38, 142-149. [CrossRef]

26. Yu, T.; Anbarasan, S.; Wang, Y.; Telli, K.; Aslan, A.S.; Su, Z.; Zhou, Y.; Zhang, L.; Iivonen, P.; Havukainen, S.; et al. Hyperthermostable Thermotoga maritima xylanase XYN10B shows high activity at high temperatures in the presence of biomass-dissolving hydrophilic ionic liquids. Extremophiles 2016, 20, 515-524. [CrossRef]

27. Zhan, P.; Ye, J.; Lin, X.; Zhang, F.; Lin, D.; Zhang, Y.; Tang, K. Complete genome sequence of Echinicola rosea JL3085, a xylan and pectin decomposer. Mar. Genom. 2019, 100722. [CrossRef]

28. Tang, K.; Lin, Y.; Han, Y.; Jiao, N. Characterization of Potential Polysaccharide Utilization Systems in the Marine Bacteroidetes Gramella Flava JLT2011 Using a Multi-Omics Approach. Front. Microbiol. 2017, 8, 220. [CrossRef]

29. Trimm, J.L.; Salama, G.; Abramson, J.J. Sulfhydryl oxidation induces rapid calcium release from sarcoplasmic reticulum vesicles. J. Biol. Chem. 1986, 261, 16092-16098. 
30. Wang, S.-Y.; Hu, W.; Lin, X.-Y.; Wu, Z.-H.; Li, Y.-Z. A novel cold-active xylanase from the cellulolytic myxobacterium Sorangium cellulosum So9733-1: Gene cloning, expression, and enzymatic characterization. Appl. Microbiol. Biotechnol. 2011, 93, 1503-1512. [CrossRef]

31. Verma, D.; Satyanarayana, T. Cloning, expression and applicability of thermo-alkali-stable xylanase of Geobacillus thermoleovorans in generating xylooligosaccharides from agro-residues. Bioresour. Technol. 2012, 107, 333-338. [CrossRef]

32. Liu, Y.-C.; Li, F.; Dong, B.; Wang, B.; Luan, W.; Zhang, X.-J.; Zhang, L.-S.; Xiang, J. Molecular cloning, characterization and expression analysis of a putative C-type lectin (Fclectin) gene in Chinese shrimp Fenneropenaeus chinensis. Mol. Immunol. 2007, 44, 598-607. [CrossRef]

33. Zhou, J.; Gao, Y.; Dong, Y.; Tang, X.; Li, J.; Xu, B.; Mu, Y.; Wu, Q.; Huang, Z. A novel xylanase with tolerance to ethanol, salt, protease, SDS, heat, and alkali from actinomycete Lechevalieria sp. HJ3. J. Ind. Microbiol. Biotechnol. 2012, 39, 965-975. [CrossRef]

34. Liu, Z.; Zhao, X.; Bai, F. Production of xylanase by an alkaline-tolerant marine-derived Streptomyces viridochromogenes strain and improvement by ribosome engineering. Appl. Microbiol. Biotechnol. 2012, 97, 4361-4368. [CrossRef] [PubMed]

35. Guo, B.; Chen, X.-L.; Sun, C.-Y.; Zhou, B.-C.; Zhang, Y.-Z. Gene cloning, expression and characterization of a new cold-active and salt-tolerant endo- $\beta-1,4$-xylanase from marine Glaciecola mesophila KMM 241. Appl. Microbiol. Biotechnol. 2009, 84, 1107-1115. [CrossRef]

36. Khandeparker, R.D.; Parab, P.; Amberkar, U. Recombinant Xylanase from Bacillus tequilensis BT21: Biochemical Characterisation and Its Application in the Production of Xylobiose from Agricultural Residues. Food Technol. Biotechnol. 2017, 55, 164-172. [CrossRef]

37. Han, Z.; Shang-Guan, F.; Yang, J. Characterization of a novel cold-active xylanase from Luteimonas species. World J. Microbiol. Biotechnol. 2018, 34, 123. [CrossRef]

38. Teo, S.C.; Liew, K.J.; Shamsir, M.S.; Chong, C.S.; Bruce, N.C.; Chan, K.-G.; Goh, K.M. Characterizing a Halo-Tolerant GH10 Xylanase from Roseithermus sacchariphilus Strain RA and Its CBM-Truncated Variant. Int. J. Mol. Sci. 2019, 20, 2284. [CrossRef]

39. Bai, W.; Xue, Y.; Zhou, C.; Ma, Y. Cloning, expression and characterization of a novel salt-tolerant xylanase from Bacillus sp. SN5. Biotechnol. Lett. 2012, 34, 2093-2099. [CrossRef]

40. Carli, S.; Meleiro, L.P.; Rosa, J.C.; De Moraes, L.A.B.; Jorge, J.A.; Masui, D.C.; Furriel, R.P. A novel thermostable and halotolerant xylanase from Colletotrichum graminicola. J. Mol. Catal. B Enzym. 2016, 133, S508-S517. [CrossRef]

41. Chen, S.; Kaufman, M.G.; Miazgowicz, K.L.; Bagdasarian, M.; Walker, E.D. Molecular characterization of a cold-active recombinant xylanase from Flavobacterium johnsoniae and its applicability in xylan hydrolysis. Bioresour. Technol. 2012, 128, 145-55. [CrossRef] [PubMed]

42. Liu, Q.; Wang, Y.; Luo, H.; Wang, L.; Shi, P.; Huang, H.; Yang, P.; Yao, B. Isolation of a Novel Cold-Active Family 11 Xylanase from the Filamentous Fungus Bispora antennata and Deletion of its N-Terminal Amino Acids on Thermostability. Appl. Biochem. Biotechnol. 2014, 175, 925-936. [CrossRef] [PubMed]

43. Collins, T.; Meuwis, M.-A.; Stals, I.; Claeyssens, M.; Feller, G.; Gerday, C. A Novel Family 8 Xylanase, Functional and Physicochemical Characterization. J. Biol. Chem. 2002, 277, 35133-35139. [CrossRef] [PubMed]

44. Shi, P.; Tian, J.; Yuan, T.; Liu, X.; Huang, H.; Bai, Y.; Yang, P.; Chen, X.; Wu, N.; Yao, B. Paenibacillus sp. Strain E18 Bifunctional Xylanase-Glucanase with a Single Catalytic Domain. Appl. Environ. Microbiol. 2010, 76, 3620-3624. [CrossRef] [PubMed]

45. Zhou, J.; Huang, H.; Meng, K.; Shi, P.; Wang, Y.; Luo, H.; Yang, P.; Bai, Y.; Zhou, Z.; Yao, B. Molecular and biochemical characterization of a novel xylanase from the symbiotic Sphingobacterium sp. TN19. Appl. Microbiol. Biotechnol. 2009, 85, 323-333. [CrossRef]

46. Fukuchi, S.; Yoshimune, K.; Wakayama, M.; Moriguchi, M.; Nishikawa, K. Unique Amino Acid Composition of Proteins in Halophilic Bacteria. J. Mol. Biol. 2003, 327, 347-357. [CrossRef]

47. Burg, B.V.D. Extremophiles as a source for novel enzymes. Curr. Opin. Microbiol. 2003, 6, 213-218. [CrossRef]

48. A Jolley, K.; Russell, R.J.M.; Hough, D.W.; Danson, M.J. Site-Directed Metagenesis and Halophilicity of Dihydrolipoamide Dehydrogenase from the Halophilic Archaeon, Haloferax Volcanii. JBIC J. Biol. Inorg. Chem. 1997, 248, 362-368. [CrossRef] 
49. Xie, H.; Flint, J.; Vardakou, M.; Lakey, J.H.; Lewis, R.J.; Gilbert, H.J.; Dumon, C. Probing the Structural Basis for the Difference in Thermostability Displayed by Family 10 Xylanases. J. Mol. Biol. 2006, 360, 157-167. [CrossRef]

50. Zheng, Y.; Li, Y.; Liu, W.; Chen, C.-C.; Ko, T.-P.; He, M.; Xu, Z.; Liu, M.; Luo, H.-Y.; Guo, R.-T.; et al. Structural insight into potential cold adaptation mechanism through a psychrophilic glycoside hydrolase family 10 endo- $\beta-1,4$-xylanase. J. Struct. Biol. 2016, 193, 206-211. [CrossRef]

51. Siddiqui, K.S.; Cavicchioli, R. Cold-Adapted Enzymes. Annu. Rev. Biochem. 2006, 75, 403-433. [CrossRef]

52. Bentahir, M.; Feller, G.; Aittaleb, M.; Lamotte-Brasseur, J.; Himri, T.; Chessa, J.-P.; Gerday, C. Structural, Kinetic, and Calorimetric Characterization of the Cold-active Phosphoglycerate Kinase from the AntarcticPseudomonassp. TACII18. J. Biol. Chem. 2000, 275, 11147-11153. [CrossRef] [PubMed]

53. Hoyoux, A.; Jennes, I.; Dubois, P.; Genicot, S.; Dubail, F.; François, J.M.; Baise, E.; Feller, G.; Gerday, C. Cold-Adapted $\beta$-Galactosidase from the Antarctic Psychrophile Pseudoalteromonas haloplanktis. Appl. Environ. Microbiol. 2001, 67, 1529-1535. [CrossRef] [PubMed]

54. Lonhienne, T.; Zoidakis, J.; E Vorgias, C.; Feller, G.; Gerday, C.; Bouriotis, V. Modular structure, local flexibility and cold-activity of a novel chitobiase from a psychrophilic antarctic bacterium. J. Mol. Biol. 2001, 310, 291-297. [CrossRef] [PubMed]

55. Liang, P.; Sun, J.; Li, H.; Liu, M.; Xue, Z.; Zhang, Y. Echinicola rosea sp. nov., a marine bacterium isolated from surface seawater. Int. J. Syst. Evol. Microbiol. 2016, 66, 3299-3304. [CrossRef]

56. He, J.; Sakaguchi, K.; Suzuki, T. Acquired Tolerance to Oxidative Stress in Bifidobacterium longum 105-A via Expression of a Catalase Gene. Appl. Environ. Microbiol. 2012, 78, 2988-2990. [CrossRef]

57. Waterhouse, A.; Bertoni, M.; Bienert, S.; Studer, G.; Tauriello, G.; Gumienny, R.; Heer, F.T.; Beer, T.A.P.; Rempfer, C.; Bordoli, L.; et al. SWISS-MODEL: Homology modelling of protein structures and complexes. Nucleic Acids. Res. 2018, 46, W296-W303. [CrossRef]

58. Williams, C.J.; Headd, J.J.; Moriarty, N.W.; Prisant, M.G.; Videau, L.L.; Deis, L.N.; Verma, V.; Keedy, D.A.; Hintze, B.; Chen, V.B.; et al. MolProbity: More and better reference data for improved all-atom structure validation. Protein Sci. 2018, 27, 29-315. [CrossRef]

59. Lüthy, R.; Bowie, J.U.; Eisenberg, D. Assessment of protein models with three-dimensional profiles. Nature 1992, 356, 83-85. [CrossRef]

60. Armenteros, J.J.A.; Tsirigos, K.; Sønderby, C.K.; Petersen, T.N.; Winther, O.; Brunak, S.; Von Heijne, G.; Nielsen, H. SignalP 5.0 improves signal peptide predictions using deep neural networks. Nat. Biotechnol. 2019, 37, 420-423. [CrossRef]

61. Robert, X.; Gouet, P. Deciphering key features in protein structures with the new ENDscript server. Nucleic Acids Res. 2014, 42, W320-W324. [CrossRef] [PubMed]

62. Ceroni, A.; Passerini, A.; Vullo, A.; Frasconi, P. DISULFIND: A disulfide bonding state and cysteine connectivity prediction server. Nucleic Acids Res. 2006, 34, W177-W181. [CrossRef] [PubMed] 